\title{
Effect of Pre-Cooling on Post Harvest Life of Mango (Mangifera Indica L.) CV. Kesar
}

\author{
Makwana S.A., Polara N.D.* , Viradia R.R. \\ Department of Horticulture, College of Agriculture, Junagadh Agricultural University, Junagadh - 362001 (Gujarat), India \\ *Corresponding Author: ndpolara@jau.in
}

Copyright $@ 2014$ Horizon Research Publishing All rights reserved.

\begin{abstract}
An experiment was carried out to study effect of pre-cooling on post harvest life of mango cv. Kesar at the Post Graduate Laboratory of the Department of Horticulture, Junagadh Agricultural University, Junagadh. The results of the study indicated that mango fruits treated with different pre-cooling treatment showed lower and slower rate in physical and chemical changes than control fruits. The fruits treated with pre-cooling at $8^{\circ} \mathrm{C}$ for $8 \mathrm{hr}$ proved to be most effective with respect to more number of days taken to ripe (11.50), longer shelf life (17.49 days), lower spoilage $(20.55 \%)$ and higher percentage of marketable fruits $(55.48 \%)$ and recorded less physiological loss in weight $(21.59 \%)$ and more firmness of fruits $\left(0.79 \mathrm{~kg} \mathrm{~cm}^{-2}\right)$ at $20^{\text {th }}$ days after storage. The treatment was also found promising for slower increase in TSS, reducing sugar and total sugar, while slower decrease in ascorbic acid and acidity during storage. The organoleptic rating with regard to colour, taste and overall acceptability was also found significantly higher in pre-cooling at $8^{\circ} \mathrm{C}$ for $8 \mathrm{hr}$ treated fruits.
\end{abstract}

Keywords Pre-Cooling, Post Harvest Life, Mango

\section{Introduction}

The mango (Mangifera indica L.) is a delicious fruit. Besides its fine taste, high palatability, sweet fragrance, attractive colour and nutritional value, it is called as 'the king of fruits' and is also a national fruit of India. It is good source of vitamin A, B-complex and $\mathrm{C}$ and $\beta$-carotene. India is the largest producer of mango occupies about 2315 thousand hectares of area under cultivation, 151.47 lakh tone production and 15.28 MT/ha productivity. In Gujarat, the total area under mango cultivation is 136.18 thousand hectares with 9.66 lakh tones production and 7.09 tonnes ha $^{-1}$ productivity (Anon., 2012). Post harvest handling is the problem of mango as due to climacteric nature of the fruit. So, post harvest handling can play a major role to reduce the losses. The post harvest losses in mango are about 25 to 30 per cent post harvest losses. This is mainly due to the non availability of commercial low temperature store houses, lack of cool chain during transport and storage (Krishnamurthy and Rao, 2001). However, mango is highly perishable, ripen faster during summer and unfit for consumption very soon. Pre-cooling of mango is very recent concept in post harvest technology but, has a great importance especially in export of mangoes. General aim of pre-cooling is to remove field heat and slower down the respiration which helps in minimizing the susceptibility to microbes and reduce water loss and thereby increase shelf life. The pre-cooling at 12 and $16^{\circ} \mathrm{C}$ temperature resulted in improving the quality of ripened fruits and delayed ripening with the extension of shelf life by about 4 days than control also completely inhibited the incidence of stem end rot and anthracnose till $13^{\text {th }}$ day of storage with or without fungicidal treatment in mango cv. Kesar (Kapse, 1993). Therefore, there is a need to regulate it's ripening so as to improve its shelf life. For that purpose pre-cooling is one of the primary post harvest operation with aim is to remove the field heat and increase shelf life of mango fruits. So, an investigation was taken to study the effect of pre-cooling temperature on ripening process and quality of Kesar mango.

\section{Materials and Methods}

The healthy, uniform in size and shape, free from any bruising and mechanical injured fruits of mango cv. Kesar was selected and cleaned by washing under cold tap water then wiped with muslin cloth. Initial weight and girth of fruits were recorded and placed in different carats and were kept in pre-cooling chamber for different treatments. The trial was conducted at the Post Graduate Laboratory of the Department of Horticulture, Junagadh Agricultural University, Junagadh with Completely Randomized Design with three repetition having total thirteen treatments like $T_{1-}$ Control, $\mathrm{T}_{2}$ - Pre-cooling at $6^{\circ} \mathrm{C}$ for 2 hours, $\mathrm{T}_{3}$ - Pre-cooling at $6^{\circ} \mathrm{C}$ for 5 hours, $\mathrm{T}_{4}$ - Pre-cooling at $6^{\circ} \mathrm{C}$ for 8 hours, $\mathrm{T}_{5^{-}}$ Pre-cooling at $8^{\circ} \mathrm{C}$ for 2 hours, $\mathrm{T}_{6}$ - Pre-cooling at $8^{\circ} \mathrm{C}$ for 5 hours, $\mathrm{T}_{7}$ - Pre-cooling at $8^{\circ} \mathrm{C}$ for 8 hours, $\mathrm{T}_{8^{-}}$- Pre-cooling at $10^{\circ} \mathrm{C}$ for 2 hours, $\mathrm{T}_{9}$ - Pre-cooling at $10^{\circ} \mathrm{C}$ for 5 hours, $\mathrm{T}_{10^{-}}$ Pre-cooling at $10^{\circ} \mathrm{C}$ for 8 hours, $\mathrm{T}_{11^{-}}$Pre-cooling at $12^{\circ} \mathrm{C}$ for 2 hours, $\mathrm{T}_{12^{-}}$Pre-cooling at $12^{\circ} \mathrm{C}$ for 5 hours and $\mathrm{T}_{13^{-}}$ 
Pre-cooling at $12^{\circ} \mathrm{C}$ for 8 hours. After treatment fruits were kept in carats under open condition at room temperature $(25$ to $28^{\circ} \mathrm{C}$ ). Two fruits from each repetition were randomly selected at a time and used for bio-chemical analysis as well as organoleptic test. The organoleptic evaluation for assessing the fruit colour, pulp colour, taste and overall acceptability was done by a panel of five judges by using 10 points scale system. The Analysis was done at five days interval and all the observations were recorded till the fruits were over ripe. Fruits were weighed on the first day of treatment and their weight was recorded. Subsequently at 5 days interval, their weights were recorded and the physiological loss in weight was expressed as percentage over the initial weight. Each fruit amongst the different treatments were thoroughly scrutinized for any visible symptoms initiation of ripening which was marketable and firm was considered for days taken for ripening. The number of visibly sound fruit that can be marketed were counted and expressed as percentage over the total number of fruit at a certain days of interval. Each fruit amongst the different treatments were thoroughly scrutinized for any visible symptoms of spoilage and end of shelf life was considered when 30 per cent fruits will show over ripen, rotten or any other spoilage symptoms. Any disease incidence, rooting, blackening etc., (particularly at the stem end) on the stored fruit were counted and expressed as percentage over total number of fruits. Two fruits from each repetition were randomly selected at a time and used for chemical analysis at five days interval. Fruit pulp was homogenized in blender and used for chemical analysis of reducing and total sugar, acidity as well as ascorbic acid content was done as per the methods described by Ranganna (1979). The TSS was recorded using a hand refractometer (Erma made, Japan 0.242 Brix, No. 96/88). Firmness of mango fruit was measured destructively using a texture analyzer (Model TAXT2i) fitted with a standard penetrometer probe (SS, $5 \mathrm{~mm}$ diameter). The variety used for this study had a skin of about $2 \mathrm{~mm}$ thickness was peeled off the fruit using a knife. The probe was pushed in to the fruit flesh to a distance of $8 \mathrm{~mm}$ at two locations along the equator of the fruit and the average values were reported. The operating conditions were:Pre-test speed $1.5 \mathrm{~mm} / \mathrm{s}$, Test speed $0.5 \mathrm{~mm} / \mathrm{s}$, Post test speed 10 $\mathrm{mm} / \mathrm{s}$. The maximum force encountered by the fruit tissue was recorded as its firmness (Jha et al., 2006).

\section{Results and Discussion}

\subsection{Physical Parameters}

The physiological loss in weight of mango fruits cv. Kesar was significantly altered by different pre-cooling treatments
(Fig. 1 to 3). The per cent physiological loss in weight significantly increased with increasing storage period from $5^{\text {th }}$ to $20^{\text {th }}$ days after storage. The minimum percentage of physiological loss was recorded when mango fruit pre-cooled at $8^{\circ} \mathrm{C}$ temperature for 8 hours $\left(\mathrm{T}_{7}\right)$. This might be due to reduction in rate of respiration and evapotranspiration as well delaying in ripening due to restricted ethylene accumulation in the treated fruits. Patel (2006) reported that the physiological loss in weight in mango could be decreased by pre-cooling treatment. In the initial period $\left(5^{\text {th }}\right)$ days of storage, marketable fruit percentage was significantly more in fruits treated with pre-cooling treatments at $8^{\circ} \mathrm{C}$ for 8 hours $\left(\mathrm{T}_{7}\right)$. However on $10^{\text {th }}$ and $15^{\text {th }}$ days pre-cooling treatments attained good quality, it was because of hastened ripening by increasing TSS, reducing titrable acidity and the colour development was better and texture was pleasing. Corroborative results have been obtained by Galathia (2004) and Joshi et al. (1993). The spoilage symptoms were minimum in fruits treated with pre-cooled at $8^{\circ} \mathrm{C}$ temperature for 8 hours (T7) during all the storage period. It reduced spoilage fruit percentage by prolonging keeping quality. The antisenescent properties help in maintaining the fruits on fresh condition during storage. The increased spoilage in hot water $50 \pm 2^{\circ} \mathrm{C}$ is due to activated enzymatic processes at higher temperature which enhanced the rate of various physiological and degradative processes also confirmed by Thangraj and Irulappan (1988) in mango and Ashwani Kumar and Dhawan (1995) in Dashehari.

The initiation of ripening process was found to be slower in mango fruits cv. Kesar when pre-cooled at $8^{\circ} \mathrm{C}$ for 8 hours $\left(\mathrm{T}_{7}\right)$. Moreover, other pre-cooling treatments have also been delayed initiation of ripening process as compared to control (Table 1). All the treatments consisting pre-cooling temperatures and periods extended shelf-life of mango fruits as compared to control and the maximum shelf life was recorded in $T_{7}$ treatment which was at par with $T_{10}$. This might be due to the reduction in field heat in shortest possible time, lower moisture loss, restricted metabolic and respiratory activities and inhibition in water loss and reduction in ethylene production in fruits (Hardenberg et al., 1990). These results are in agreement with the results of Dhemre (2001) and Sondkar (2002) in mango. A fall in firmness in all the treatments was observed during storage period. Maximum fruit firmness was recorded in fruits treated with pre-cooling of mango at $8^{\circ} \mathrm{C}$ for 8 hours. Gradual conversions of carbohydrate into sugar lead to the decrease in firmness along with change in cell wall polysaccharides and uronic acid. Decline in alkali soluble pectin and increase in polygalactouranase activity was found to be correlated with the loss of firmness. These results are also supported by Illangantileke and Salonkhe (1990) and Singh (1990) in mango. 
Table 1. Effect of pre-cooling on ripening, shelf life and fruit firmness mango cv. Kesar during storage at ambient temperature

\begin{tabular}{|c|c|c|c|c|c|c|c|}
\hline \multirow{2}{*}{ Treatments } & \multirow{2}{*}{$\begin{array}{c}\text { Days to } \\
\text { ripening }\end{array}$} & \multirow{2}{*}{$\begin{array}{c}\text { Shelf life } \\
\text { (Days) }\end{array}$} & \multicolumn{5}{|c|}{ Firmness $\left(\mathrm{kg} / \mathrm{cm}^{2}\right)$} \\
\cline { 4 - 8 } & & 0 day & $5^{\text {th }}$ day & $10^{\text {th }}$ day & $15^{\text {th }}$ day & $20^{\text {th }}$ day \\
\hline $\mathrm{T}_{1}$ & 9.71 & 12.19 & 9.24 & 6.27 & 1.23 & 0.70 & 0.42 \\
\hline $\mathrm{T}_{2}$ & 10.33 & 13.70 & 9.13 & 6.62 & 2.53 & 0.73 & 0.93 \\
\hline $\mathrm{T}_{3}$ & 10.96 & 14.80 & 9.19 & 6.75 & 3.46 & 1.66 & 0.47 \\
\hline $\mathrm{T}_{4}$ & 11.32 & 15.07 & 9.24 & 6.99 & 2.27 & 0.92 & 0.80 \\
\hline $\mathrm{T}_{5}$ & 10.46 & 15.20 & 9.46 & 6.09 & 2.40 & 1.06 & 0.81 \\
\hline $\mathrm{T}_{6}$ & 11.18 & 15.62 & 9.41 & 6.31 & 2.62 & 1.56 & 0.75 \\
\hline $\mathrm{T}_{7}$ & 11.50 & 17.49 & 9.42 & 6.84 & 2.56 & 0.90 & 0.79 \\
\hline $\mathrm{T}_{8}$ & 10.65 & 15.22 & 9.24 & 6.22 & 1.27 & 1.25 & 0.47 \\
\hline $\mathrm{T}_{9}$ & 11.07 & 15.49 & 9.23 & 6.98 & 2.13 & 1.34 & 0.56 \\
\hline $\mathrm{T}_{10}$ & 11.42 & 15.87 & 9.35 & 5.71 & 1.80 & 1.20 & 0.48 \\
\hline $\mathrm{T}_{11}$ & 10.81 & 15.27 & 9.35 & 6.54 & 2.71 & 1.39 & 0.84 \\
\hline $\mathrm{T}_{12}$ & 11.00 & 15.37 & 9.35 & 5.82 & 2.52 & 1.23 & 0.54 \\
\hline $\mathrm{T}_{13}$ & 11.25 & 15.56 & 9.38 & 6.92 & 2.19 & 0.91 & 0.75 \\
\hline $\mathrm{S} . \mathrm{Em} . \pm$ & 0.28 & 0.60 & 0.15 & 0.30 & 0.07 & 0.03 & 0.02 \\
\hline $\mathrm{CD}$ at $5 \%$ & 0.87 & 1.84 & $\mathrm{NS}$ & $\mathrm{NS}$ & 0.21 & 0.08 & 0.06 \\
\hline $\mathrm{CV} \%$ & 3.68 & 5.67 & 2.78 & 7.94 & 5.42 & 4.04 & 5.39 \\
\hline
\end{tabular}

\subsection{Organoleptic Score}

Organoleptic characters of mango and sapota like fruit colour, pulp colour and taste showed the highest score in the fruits when treated with pre-cooling at $8^{\circ} \mathrm{C}$ for 8 hours (Table 2 and Fig. 4 to7). Similar trend was recorded by Singh et al. (2003) in mango. The biochemical constituents of mango pulp can be correlated with organoleptic characters (Kapse, 1993).

\subsection{Biochemical Parameters}

The total soluble solids of mango fruits $\mathrm{cv}$. Kesar were not significantly affected due to different pre-cooling treatments on $5^{\text {th }}$ day after storage, while during later period; it was remained significant up to $20^{\text {th }}$ days of storage (Table 3 and Fig. 8 to 12). The mango fruit cv. Kesar pre-cooled at $8^{\circ} \mathrm{C}$ temperature for 8 hours $\left(\mathrm{T}_{7}\right)$ increased TSS slowly due to accumulation of sugar at lower rate. Slower increment in TSS under treatment $\mathrm{T}_{7}$ might be due to pre-cooling immediately after the harvest reduced field heat from the fruit which restricted respiratory activities and inhibited water loss. Both reducing and total sugar content showed increasing trend during storage period. This may be a consequence of release of sugar during starch hydrolysis and liberating reducing sugars (Kapse, 1993). The accumulation of reducing sugar and total sugar were slow and gradual in fruits stored in cold storage $8^{\circ} \mathrm{C}$. The higher value of total sugar and reducing sugar due to arrested respiration in ambient stored fruits. It can also be observed that reducing sugars and total sugar content were reduced in the later period of storage. This may be due to their rapid utilization in respiration.

The titrable acidity was not influenced under different pre-cooling treatments on $5^{\text {th }}$ day after storage and was significant afterward up to $20^{\text {th }}$ day of storage. From $5^{\text {th }}$ to $20^{\text {th }}$ days after storage, the maximum titrable acidity was recorded in mango $\mathrm{cv}$. Kesar fruits when pre-cooled at $8^{\circ} \mathrm{C}$ temperature for 8 hours $\left(\mathrm{T}_{7}\right)$. The treatments comprising pre-cooling treatments might be responsible for slower conversion of acids into sugars and utilization of acids during storage period (respiration) as compared to control (no pre-cooling). This might be due to delayed ripening by pre-cooling treatments. These finding are in line with the finding of Puttaraju and Reddy (1997) in mango.

The ascorbic acid content of fruits decreased gradually during storage in all the treatments. Maximum ascorbic acid content was observed in pre-cooling $8^{\circ} \mathrm{C}$ for $8 \mathrm{hr}$. The pre-cooling treatment retards the ripening process and slows down the respiration of fruits and therefore higher level of ascorbic acid was observed. This might have happened due to rapid conversion of ascorbic acid in to dehydro-ascorbic acid in the presence of enzyme ascorbinase with different level of oxidation in different treatments (Mapson, 1970). The results conformed to the findings of Trivedi and Desai (2006) in guava. 
Table 2. Effect of pre-cooling on organoleptic score* for different tests of mango cv. Kesar during storage at ambient temperature

\begin{tabular}{|c|c|c|c|c|c|c|c|c|c|c|c|c|c|c|c|c|}
\hline \multirow[t]{2}{*}{ Treatments } & \multicolumn{4}{|c|}{ Fruit colour } & \multicolumn{4}{|c|}{ Pulp colour } & \multicolumn{4}{|c|}{ Fruit taste } & \multicolumn{4}{|c|}{ Overall acceptability } \\
\hline & $5^{\text {th }}$ day & $10^{\text {th }}$ day & $15^{\text {th }}$ day & $20^{\text {th }}$ day & $5^{\text {th }}$ day & $10^{\text {th }}$ day & $15^{\text {th }}$ day & $20^{\text {th }}$ day & $5^{\text {th }}$ day & $10^{\text {th }}$ day & $15^{\text {th }}$ day & $20^{\text {th }}$ day & $5^{\text {th }}$ day & $10^{\text {th }}$ day & $15^{\text {th }}$ day & $20^{\text {th }}$ day \\
\hline $\mathrm{T}_{1}$ & 6.03 & 7.44 & 5.56 & 5.14 & 6.27 & 7.01 & 6.54 & 5.43 & 6.98 & 6.56 & 7.61 & 5.38 & 6.98 & 8.40 & 8.40 & 0.00 \\
\hline $\mathrm{T}_{2}$ & 6.58 & 7.51 & 6.76 & 5.47 & 6.74 & 7.63 & 7.44 & 6.54 & 6.09 & 7.09 & 6.98 & 5.76 & 5.94 & 7.60 & 9.03 & 8.22 \\
\hline $\mathrm{T}_{3}$ & 6.17 & 7.45 & 8.05 & 5.58 & 7.34 & 7.68 & 7.34 & 6.80 & 5.92 & 7.04 & 7.43 & 5.41 & 5.60 & 7.54 & 8.91 & 8.04 \\
\hline $\mathrm{T}_{4}$ & 5.79 & 7.90 & 7.62 & 5.33 & 6.83 & 7.35 & 7.84 & 6.63 & 6.25 & 7.38 & 7.70 & 6.56 & 5.25 & 7.29 & 8.71 & 7.96 \\
\hline $\mathrm{T}_{5}$ & 7.53 & 8.70 & 5.75 & 7.43 & 7.25 & 7.10 & 6.30 & 6.81 & 6.73 & 6.94 & 8.03 & 6.99 & 7.99 & 9.04 & 9.81 & 5.44 \\
\hline $\mathrm{T}_{6}$ & 6.22 & 8.59 & 7.27 & 7.57 & 7.06 & 7.56 & 7.03 & 6.77 & 6.68 & 7.26 & 7.85 & 6.42 & 8.04 & 8.25 & 9.83 & 0.00 \\
\hline $\mathrm{T}_{7}$ & 8.43 & 9.51 & 8.68 & 8.26 & 8.09 & 8.63 & 8.87 & 7.67 & 8.23 & 8.54 & 9.46 & 7.67 & 8.37 & 9.28 & 10.00 & 9.53 \\
\hline $\mathrm{T}_{8}$ & 6.25 & 8.09 & 7.49 & 5.35 & 6.49 & 7.66 & 7.81 & 6.87 & 6.46 & 7.28 & 7.80 & 6.48 & 6.66 & 8.17 & 9.56 & 0.00 \\
\hline $\mathrm{T}_{9}$ & 6.51 & 7.57 & 7.36 & 6.43 & 6.44 & 7.67 & 7.31 & 6.26 & 6.34 & 7.78 & 7.76 & 5.88 & 6.29 & 7.86 & 9.23 & 9.41 \\
\hline $\mathrm{T}_{10}$ & 7.29 & 8.52 & 5.60 & 6.12 & 7.30 & 7.79 & 6.79 & 6.78 & 6.99 & 6.68 & 8.26 & 6.19 & 7.66 & 8.92 & 9.73 & 0.00 \\
\hline $\mathrm{T}_{11}$ & 6.32 & 8.04 & 7.19 & 5.54 & 6.98 & 7.71 & 6.97 & 6.39 & 6.51 & 7.00 & 8.00 & 6.38 & 6.61 & 8.11 & 9.47 & 8.33 \\
\hline $\mathrm{T}_{12}$ & 7.04 & 8.39 & 6.49 & 6.05 & 7.29 & 7.22 & 7.83 & 6.72 & 6.60 & 7.33 & 7.35 & 6.74 & 7.33 & 8.66 & 9.64 & 7.01 \\
\hline $\mathrm{T}_{13}$ & 6.50 & 7.52 & 5.57 & 6.45 & 7.28 & 7.84 & 6.48 & 6.41 & 6.95 & 6.86 & 7.83 & 6.11 & 6.88 & 7.54 & 8.21 & 7.58 \\
\hline S.Em. \pm & 0.18 & 0.18 & 0.19 & 0.13 & 0.32 & 0.29 & 0.31 & 0.27 & 0.38 & 0.23 & 0.36 & 0.21 & 0.08 & 0.07 & 0.05 & 0.03 \\
\hline $\mathrm{CD}$ at $5 \%$ & 0.53 & 0.52 & 0.57 & 0.38 & 0.73 & 0.78 & 0.91 & 0.78 & 1.11 & 0.68 & 1.06 & 0.62 & 0.23 & 0.20 & 0.14 & 0.09 \\
\hline $\mathrm{CV} \%$ & 4.73 & 3.82 & 4.9 & 4.62 & 7.88 & 6.55 & 7.48 & 7.06 & 9.95 & 5.59 & 8.00 & 5.88 & 1.97 & 1.45 & 0.88 & 1.06 \\
\hline
\end{tabular}

*Score out of 10 number 
Effect of Pre-Cooling on Post Harvest Life of Mango (Mangifera Indica L.) CV. Kesar

Table 3. Effect of pre-cooling on biochemical parameters of mango cv. Kesar during storage at ambient temperature

\begin{tabular}{|c|c|c|c|c|c|c|c|c|c|c|c|c|c|c|c|c|c|c|c|c|}
\hline \multirow{2}{*}{ Treatments } & \multicolumn{4}{|c|}{ Total soluble solids ( ${ }^{\circ}$ Brix) } & \multicolumn{4}{|c|}{ Reducing sugar (\%) } & \multicolumn{4}{|c|}{ Total sugar $(\%)$} & \multicolumn{4}{|c|}{ Acidity (\%) } & \multicolumn{4}{|c|}{ Ascorbic acid (mg/100 g of fresh pulp) } \\
\hline & $5^{\text {th }}$ day & $\begin{array}{l}10^{\text {th }} \\
\text { day }\end{array}$ & $\begin{array}{l}15^{\text {th }} \\
\text { day }\end{array}$ & $\begin{array}{l}20^{\text {th }} \\
\text { day }\end{array}$ & $5^{\text {th }}$ day & $\begin{array}{l}10^{\text {th }} \\
\text { day }\end{array}$ & $\begin{array}{l}15^{\text {th }} \\
\text { day }\end{array}$ & $\begin{array}{l}20^{\text {th }} \\
\text { day }\end{array}$ & $5^{\text {th }}$ day & $\begin{array}{l}10^{\text {th }} \\
\text { day }\end{array}$ & $\begin{array}{l}15^{\text {th }} \\
\text { day }\end{array}$ & $\begin{array}{l}20^{\text {th }} \\
\text { day }\end{array}$ & $5^{\text {th }}$ day & $\begin{array}{l}10^{\text {th }} \\
\text { day }\end{array}$ & $\begin{array}{l}15^{\text {th }} \\
\text { day }\end{array}$ & $\begin{array}{l}20^{\text {th }} \\
\text { day }\end{array}$ & $5^{\text {th }}$ day & $\begin{array}{l}10^{\text {th }} \\
\text { day }\end{array}$ & $\begin{array}{l}15^{\text {th }} \\
\text { day }\end{array}$ & $\begin{array}{l}20^{\text {th }} \\
\text { day }\end{array}$ \\
\hline $\mathrm{T}_{1}$ & 11.07 & 14.30 & 16.90 & 19.35 & 3.51 & 4.01 & 4.34 & 4.43 & 7.76 & 13.14 & 15.16 & 18.09 & 2.20 & 0.53 & 0.33 & 0.00 & 68.58 & 60.68 & 45.66 & 33.47 \\
\hline $\mathrm{T}_{2}$ & 11.08 & 14.34 & 17.00 & 19.48 & 3.65 & 4.11 & 4.39 & 4.52 & 8.14 & 12.46 & 15.61 & 17.88 & 2.90 & 0.58 & 0.40 & 0.16 & 70.71 & 65.57 & 47.69 & 38.71 \\
\hline $\mathrm{T}_{3}$ & 11.15 & 14.60 & 17.35 & 19.90 & 3.49 & 4.09 & 4.35 & 4.22 & 8.29 & 12.49 & 15.44 & 17.38 & 2.65 & 0.60 & 0.38 & 0.17 & 70.33 & 60.74 & 47.22 & 37.87 \\
\hline $\mathrm{T}_{4}$ & 11.45 & 15.60 & 17.72 & 21.25 & 3.55 & 4.16 & 4.64 & 4.88 & 8.26 & 13.11 & 15.01 & 16.80 & 2.60 & 1.03 & 0.62 & 0.42 & 70.89 & 64.97 & 48.52 & 38.33 \\
\hline $\mathrm{T}_{5}$ & 11.10 & 14.35 & 17.21 & 20.05 & 3.26 & 4.50 & 4.37 & 4.84 & 8.15 & 13.18 & 14.82 & 18.10 & 2.90 & 0.54 & 0.40 & 0.16 & 69.81 & 64.53 & 46.55 & 37.88 \\
\hline $\mathrm{T}_{6}$ & 11.23 & 14.80 & 17.45 & 20.25 & 3.30 & 4.04 & 4.55 & 4.71 & 7.97 & 12.24 & 15.38 & 18.58 & 2.73 & 0.91 & 0.49 & 0.22 & 70.78 & 65.37 & 47.87 & 38.20 \\
\hline $\mathrm{T}_{7}$ & 11.65 & 15.80 & 18.25 & 21.45 & 4.00 & 4.90 & 5.07 & 5.40 & 9.44 & 14.26 & 17.01 & 19.28 & 3.30 & 1.13 & 0.65 & 0.44 & 74.22 & 69.93 & 51.91 & 41.00 \\
\hline $\mathrm{T}_{8}$ & 11.12 & 14.45 & 17.27 & 19.49 & 3.32 & 4.02 & 4.25 & 4.63 & 8.00 & 12.17 & 15.43 & 17.70 & 2.36 & 0.96 & 0.49 & 0.38 & 70.39 & 65.52 & 45.90 & 36.49 \\
\hline $\mathrm{T}_{9}$ & 11.21 & 14.74 & 17.34 & 20.13 & 3.63 & 4.24 & 4.49 & 4.65 & 8.07 & 13.14 & 15.67 & 17.93 & 2.40 & 0.62 & 0.48 & 0.19 & 70.73 & 65.00 & 46.78 & 35.61 \\
\hline $\mathrm{T}_{10}$ & 11.53 & 15.71 & 18.24 & 21.25 & 3.58 & 4.13 & 4.54 & 4.28 & 7.88 & 12.14 & 15.16 & 17.93 & 3.30 & 1.10 & 0.64 & 0.42 & 69.78 & 64.02 & 46.84 & 38.81 \\
\hline $\mathrm{T}_{11}$ & 11.13 & 14.50 & 17.33 & 20.15 & 3.61 & 4.48 & 4.45 & 4.56 & 7.45 & 12.01 & 15.58 & 18.46 & 2.90 & 0.91 & 0.51 & 0.24 & 69.57 & 63.21 & 46.36 & 38.03 \\
\hline $\mathrm{T}_{12}$ & 11.20 & 14.65 & 17.38 & 20.17 & 3.41 & 4.04 & 4.16 & 4.41 & 8.07 & 13.01 & 15.51 & 18.43 & 2.85 & 0.93 & 0.40 & 0.25 & 69.61 & 64.16 & 46.36 & 37.17 \\
\hline $\mathrm{T}_{13}$ & 11.42 & 15.50 & 17.53 & 21.17 & 3.42 & 4.12 & 4.58 & 4.38 & 7.77 & 13.10 & 15.73 & 18.05 & 3.25 & 0.99 & 0.60 & 0.41 & 70.44 & 63.11 & 48.11 & 35.76 \\
\hline S.Em. \pm & 0.11 & 0.17 & 0.25 & 0.17 & 0.14 & 0.16 & 0.14 & 0.20 & 0.26 & 0.34 & 0.35 & 0.39 & 0.22 & 0.05 & 0.02 & 0.01 & 0.88 & 1.11 & 0.92 & 0.27 \\
\hline $\begin{array}{c}\text { CD at } \\
5 \%\end{array}$ & NS & 0.52 & 0.76 & 0.52 & 0.34 & 0.39 & 0.42 & 0.48 & 0.77 & 1.00 & 1.03 & 1.15 & NS & 0.15 & 0.05 & 0.03 & 2.55 & 3.22 & 2.67 & 2.52 \\
\hline $\mathrm{CV} \%$ & 1.39 & 1.62 & 2.00 & 1.19 & 6.99 & 6.70 & 5.52 & 7.43 & 5.65 & 4.64 & 3.96 & 3.78 & 11.01 & 8.08 & 4.41 & 5.09 & 2.15 & 2.98 & 3.36 & 4.01 \\
\hline
\end{tabular}


Crop Prot. Prod., 2(2): 75-78.

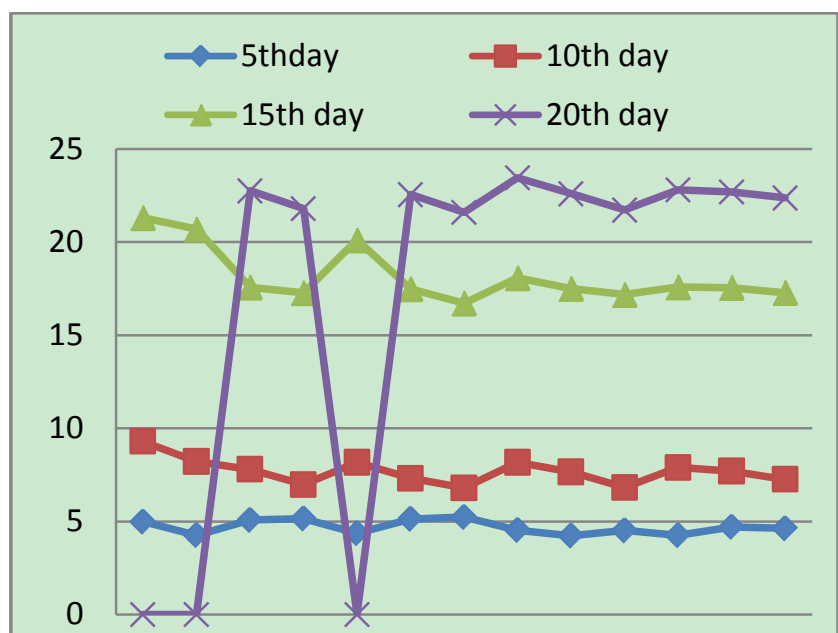

T1 T2 T3 T4 T5 T6 T7 T8 T9 T10T11T12T13

Fig. 1 Effect of pre-cooling on PLW(\%)

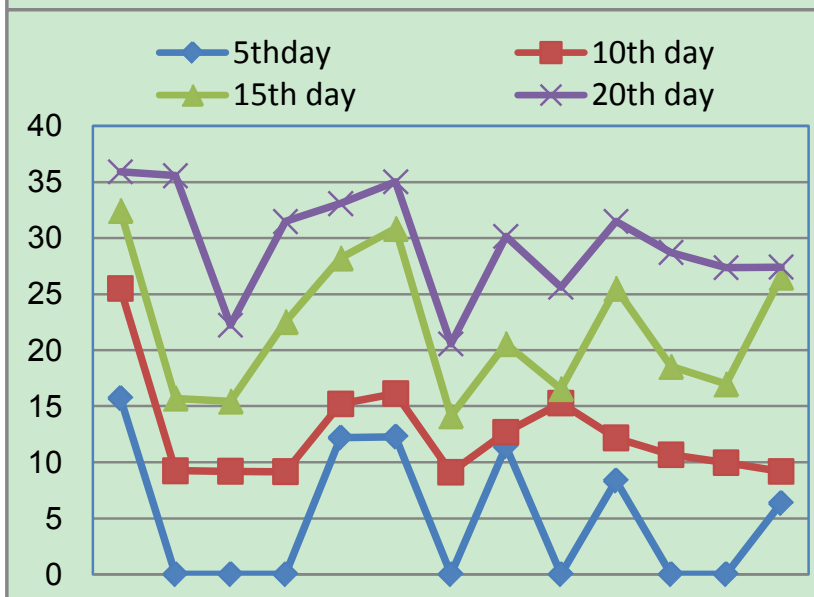

T1 T2 T3 T4 T5 T6 T7 T8 T9 T10T11T12T13 Fig. 3 Effect of pre-cooling on spoilage (\%)

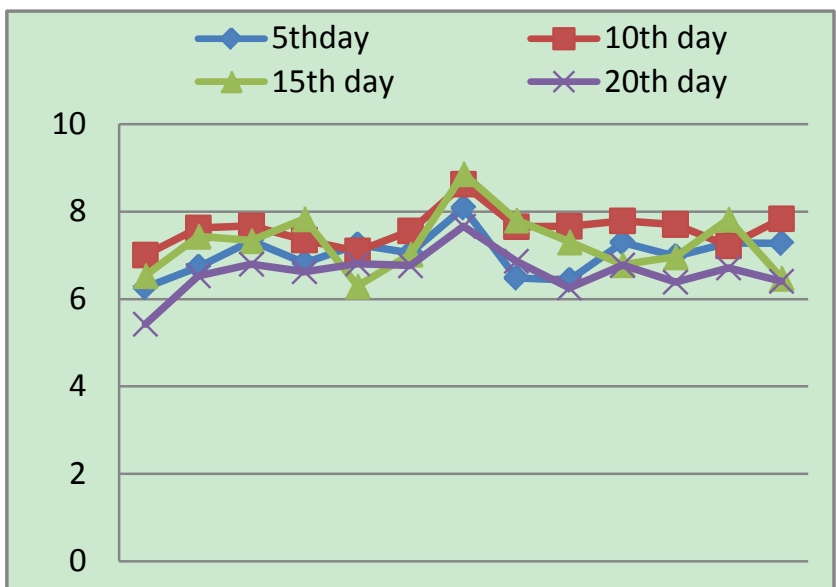

T1 T2 T3 T4 T5 T6 T7 T8 T9 T10T11T12T13

Fig. 5 Effect of pre-cooling on Pulp colour

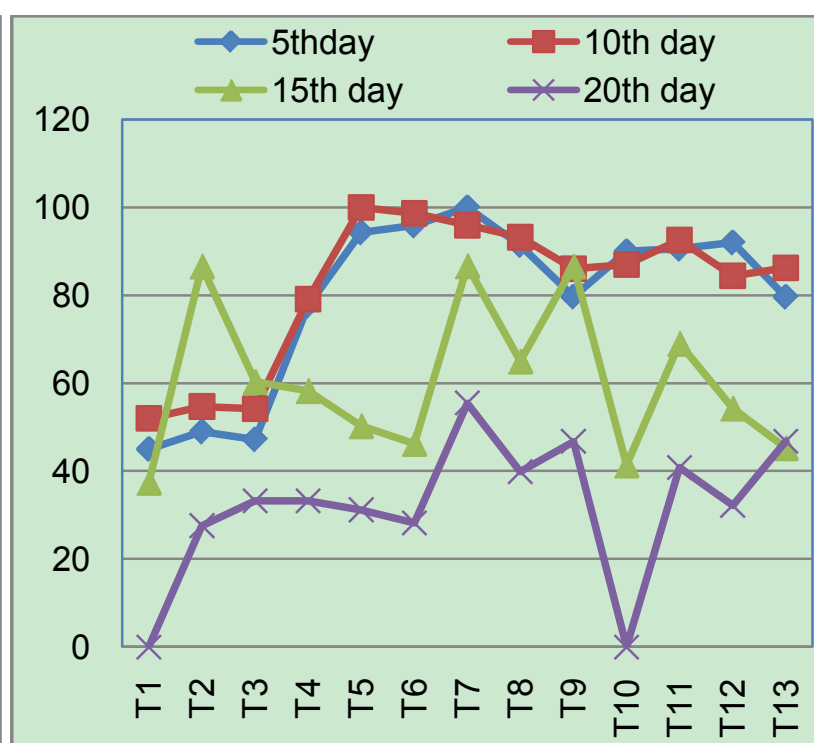

Fig. 2 Effect of pre-cooling on Marketable fruits (\%)

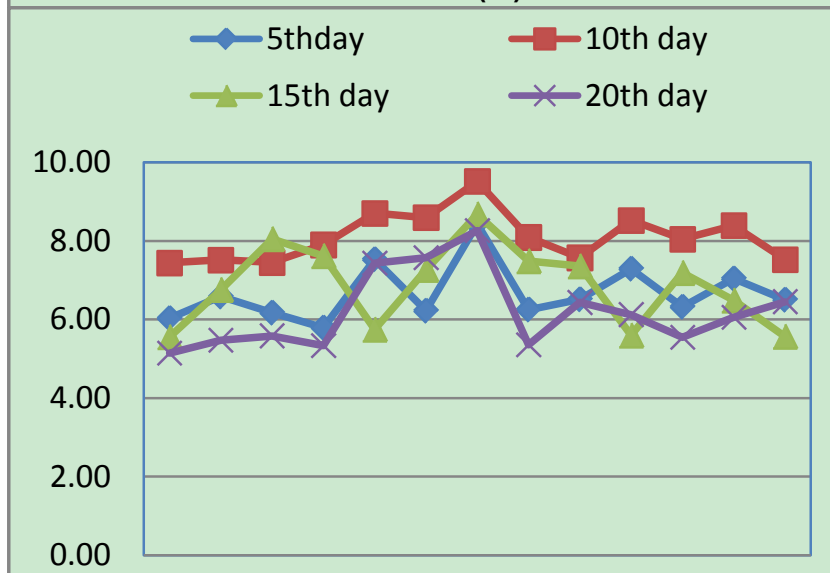

$\exists \cong \mathscr{\vdash}$

Fig. 4 Effect of pre-cooling on fruit colour

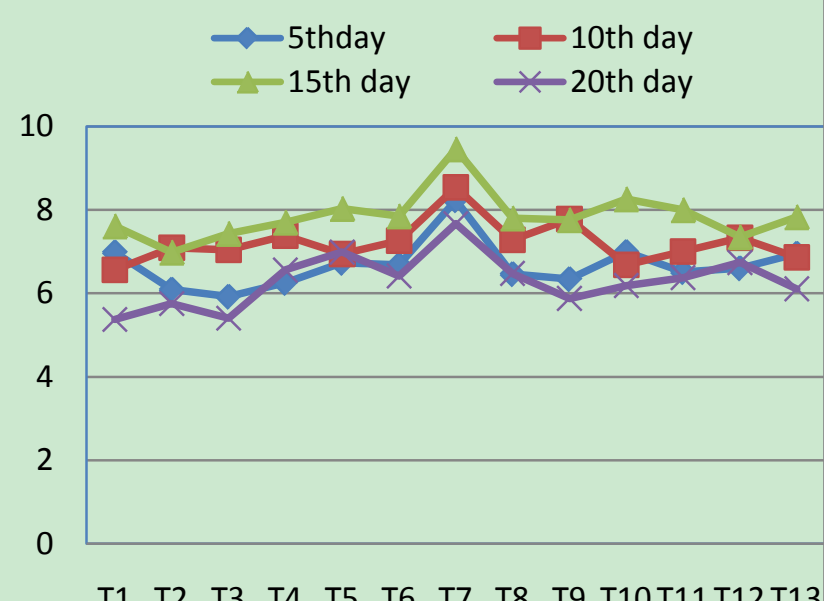

Fig. 6 Effect of pre-cooling on fruit taste 


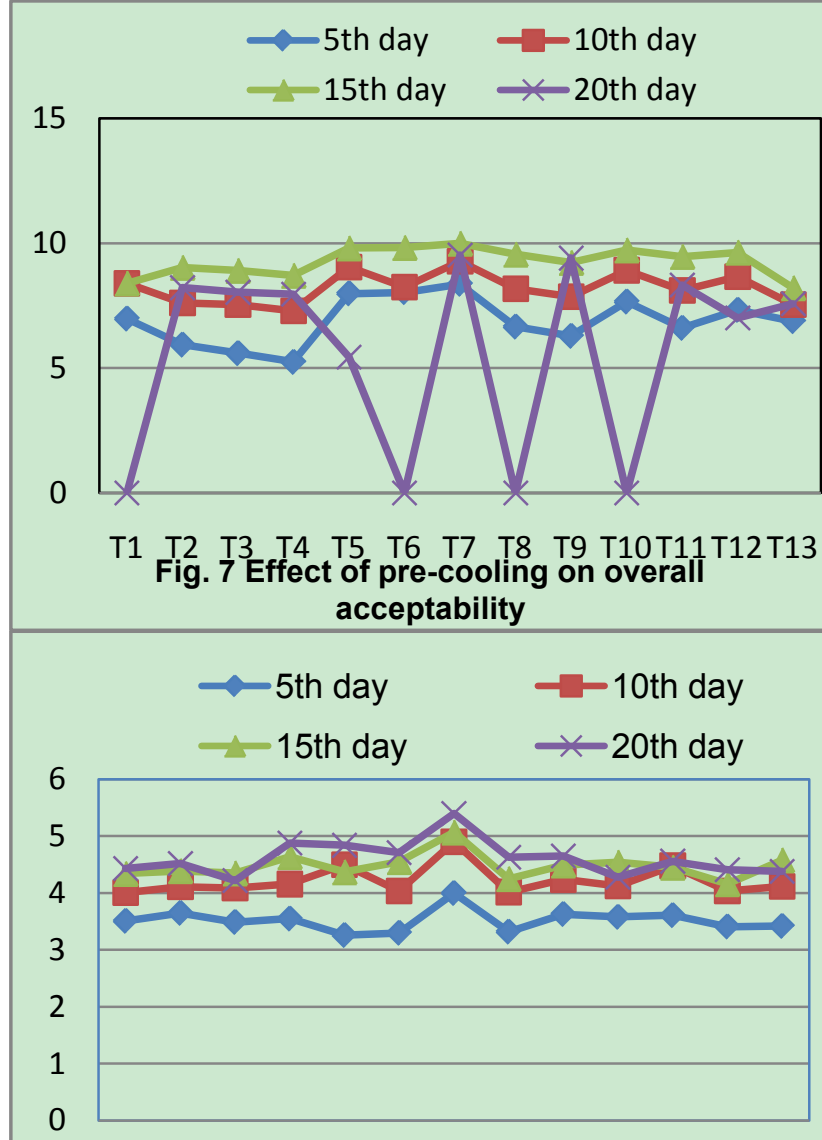

T1 $12 \quad$ T3 $\quad$ T4

Fig. 9 Effect of pre-cooling on reducing sugar (\%)

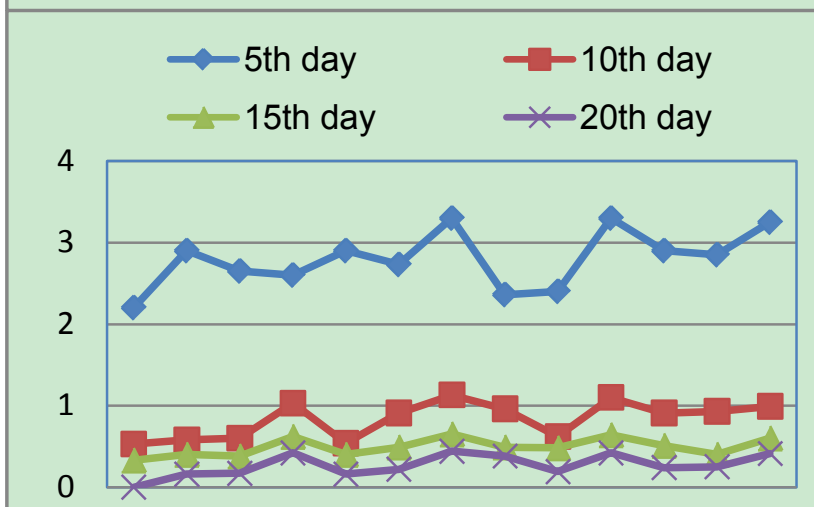

T1 T2 T3 T4 T5 T6 T7 T8 T9 T10T11T12T13

Fig. 11 Effect of pre-cooling on acidity (\%)

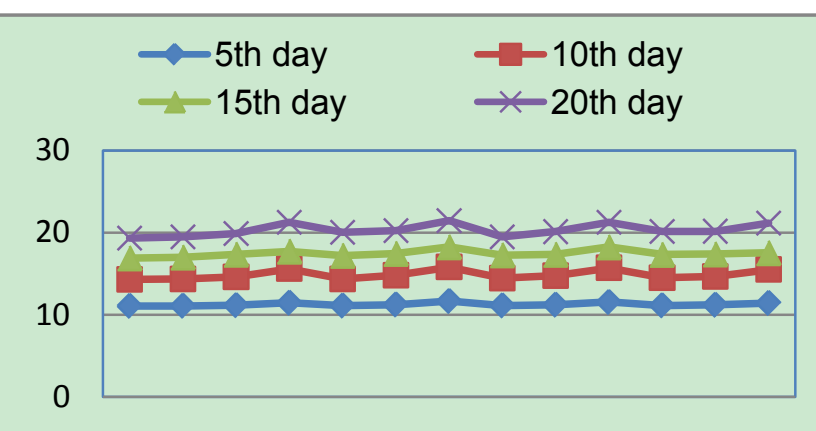

T1 T2 T3 T4 T5 T6 T7 T8 T9 T10T11T12T13

Fig. 8 Effect of pre-cooling on TSS ( ${ }^{\circ}$ Brix)

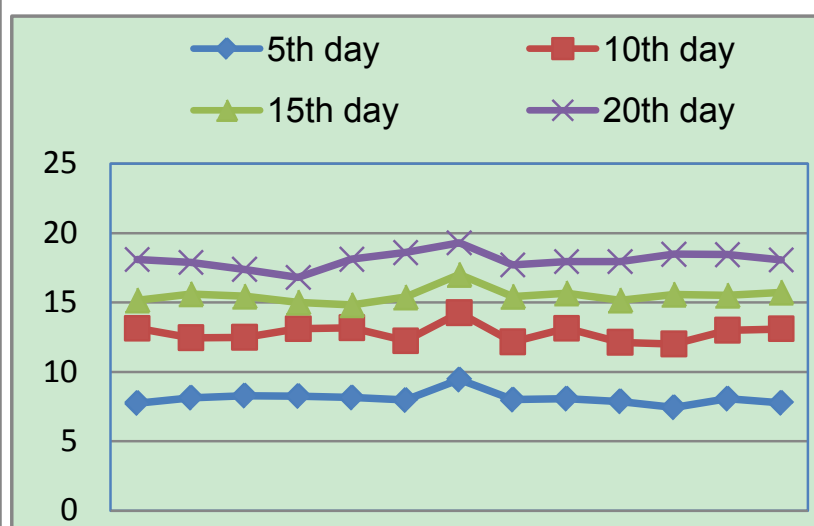

T1 T2 T3 T4 T5 T6 T7 T8 T9 T10T11T12T13

Fig. 10 Effect of pre-cooling on total sugar (\%)

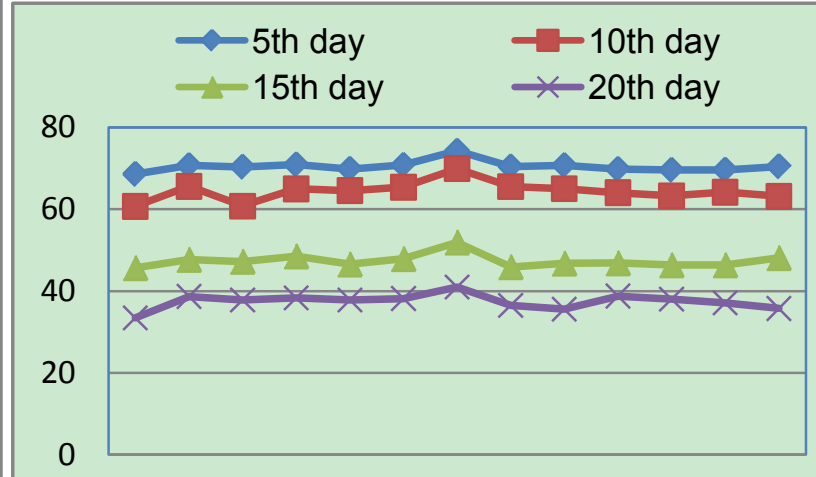

T1 T2 T3 T4 T5 T6 T7 T8 T9 T10T11T12T13

Fig. 12 Effect of pre-cooling on ascorbic acid (mg/100 $\mathrm{g}$ of fresh pulp)

\section{REFERNCES}

[1] Anonymous, (2012). Director of Horticulture, Gujarat State, Gandhinagar.

[2] Ashwani Kumar and Dhawan, S. S. (1995). Effect of post

harvest treatments on the enhancement of ripening of mango (Mangifera indica L.) fruit cv. 'Dashehari'. Haryana J. Hort. Sci., 24(2): 109-115.

[3] Dhemre, J. K. (2001). Studies on extending the shelf life of mango (Mangifera indica L.) cv. Kesar. Ph.D. thesis, Mahatma Phule Krishi Vidyapeeth, Rahuri.

[4] Galathia, M.B. (2004). Study of various post harvest treatments on shelf-life of mango (Mangifera indica L.) CV. 
Dasheri. M.Sc. (Agri.) thesis, Navsari Agricultural University, Navsari, Gujarat.

[5] Hardenburg, R. E.; Watada, A. F and Wang, C. Y. (1990). The commercial storage of fruits vegetable and florist and nursery stocks, U. S. Dept. Agr. Handbook No. 66, pp. 3.

[6] Illangantileke, S. and Salonkhe, V. (1990). Post harvest biotechnology to increase storage life of mango. Dept. of Sci. and Tech., Bicutan, Taguig, Metro Manila. ASEAN Science and Technology week: Proceeding. Vol. 2. Metro Manila (Philippines), pp. 215-230.

[7] Jha, S.N.; Kingsly, A.R.P.; Sangeeta Chopra (2006). Physical and mechanical properties of mango during growth and storage for dermination of maturity. Journal of Food Engineering, 72(1): 73-76.

[8] Joshi, G. D.; Khan, A. I. A.; Relekar, P. P. and Magdum, M. B. (1993). Effect of pre-cooling on shelf life and incidence of spongy tissue in Alphanso mango. A paper presented at G. J. Symposium held at Banglore, Abstracts, pp. 343-44.

[9] Kapse, B. M. (1993). An integrated Approach to post-harvest handling of mango. (Mangifera indica L.) cultivar Kesar. Ph.D. thesis, G.A.U., S. K. Nagar.

[10] Krishnamurthy, S. and Rao, D. V. S. (2001).Status of post harvest management of fruits. Indian J. Hort., 58(1-2): 152.

[11] Mapson, L. W. (1970). Vitamins in fruits, stability of 1-ascorbic acid. Biochemistry of fruits and their products, pp. 376-377.
[12] Patel, U.A., (2006). Effect of post harvest treatments on storage behavior of hybrid mango (Mangifera indica L.) Cv. Amrapali and Neelphonso. M.Sc. (Agri.) thesis, Navsari Agricultural University, Navsari, Gujarat.

[13] Puttaraju, T. B. and Reddy, T. V. (1997). Effect of pre-cooling on the quality of mango (cv. Mallika). J. Food Sci. and Tech., 34(1): 24-25.

[14] Ranganna, S. (1979). Manual of analysis of fruits and vegetables. Tata McGraw Hill Pub. Co. Ltd., New Delhi.

[15] Singh, Ram; Jitender, Kumar and Goyal, R. K. (2003). Effect of oil emulsions and pre-cooling on shelf life of mango cv. Amarapali. Haryana J. Hort. Sci., 32(1\&2): 54-55.

[16] Singh, B. P. (1990). Effect of pre-cooling temperature and fungicide on storage of mango fruits cv. Dashehari and Langra. Annual Report, CISH, Lucknow, 1990. pp. 52-56.

[17] Sondkar, S. A. (2002). Studies on effect of pre-cooling and storage on shelf-life of mango. B. Tech. Thesis. Mahatma Phule Krishi Vidyapeeth, Rahuri.

[18] Thangarajan, T. and Irulappan I. (1988). Effectiveness of hot water treatment, waxing and cool chamber storage in prolonging the shelf life of mango. South Indian Hort., 36(6): 327-328.

[19] Trivedi, Y.V. and Desai, M.M. (2006). Effect of different storage techniques and conditions on quality and shelf life of guava fruits. 